\title{
Thermal stability responses of soil organic matter to long-term fertilization practices
}

\author{
J. Leifeld ${ }^{1}$, U. Franko ${ }^{2}$, and E. Schulz ${ }^{2}$ \\ ${ }^{1}$ Air Pollution/Climate Group, Agroscope Reckenholz-Tänikon Research Station ART, Zurich, Switzerland \\ ${ }^{2}$ UFZ-Umweltforschungszentrum Leipzig-Halle, Germany
}

Received: 18 January 2006 - Published in Biogeosciences Discuss.: 4 April 2006

Revised: 9 June 2006 - Accepted: 27 June 2006 - Published: 25 July 2006

\begin{abstract}
We used differential scanning calorimetry (DSC) to infer thermal properties of soil organic matter (SOM) in the static fertilization experiment in Bad Lauchstädt, Germany, which has been established in 1902. Four treatments (null N, change from null to manuring in $1978 \mathrm{NM}$, change from manuring to null in $1978 \mathrm{MN}$, and permanent manure and mineral fertilization since $1902 \mathrm{M}$ ) were sampled in 2004. Soil organic carbon contents were highest for $\mathrm{M}$ (2.4\%), lowest for $\mathrm{N}(1.7 \%)$, and similar for $\mathrm{MN}$ and $\mathrm{NM}$ (2.2\%). Three heat flow peaks at around $354^{\circ} \mathrm{C}, 430^{\circ} \mathrm{C}$, and $520^{\circ} \mathrm{C}$, which were assigned to as thermally labile and stable SOM and combustion residues from lignite, respectively, characterized DSC thermograms. DSC peak temperatures were relatively constant among treatments, but peak heights normalized to the organic $\mathrm{C}$ content of the soil were significantly different for labile and stable SOM. Labile $\mathrm{C}$ was higher for $\mathrm{M}>\mathrm{MN}=\mathrm{NM}=\mathrm{N}$, and stable $\mathrm{C}$ decreased in the order $\mathrm{N}=\mathrm{NM}>\mathrm{MN}=\mathrm{M}$, showing that agricultural depletion of SOM increases the share of thermally stable C. Lignitederived $\mathrm{C}$ was not affected by management, suggesting a homogeneous deposition across treatments.
\end{abstract}

\section{Introduction}

Measurement of the thermal behaviour of organic matter under oxidative conditions allows separating thermally labile and stable compounds by means of measuring peak temperatures, for example. It has been suggested that the thermal stability of plant tissue is closely related to its chemistry (Shafizadeh, 1984), but the conceptual linkage between chemical and physical properties of organic matter in soil and its thermal reactivity is less straightforward. For sites under

Correspondence to: J. Leifeld

(jens.leifeld@art.admin.ch) contrasting agricultural land-use, Lopez-Capel et al. (2005) showed that free and intra-aggregate light fractions of soil organic matter (SOM) are characterized by typical thermal responses and that thermal and chemical attributes of the organic matter were correlated. Also clay fractions in chronosequences from native forest to long-term bare fallow differed in their thermal stability and the bare fallow was relatively enriched in stable organic matter (Plante et al. 2005). Unlike soil fractions, the analysis of bulk soils requires no time-consumptive sample pre-treatment and has been applied previously (e.g. Satoh, 1984). However, because organic matter in soil fractions is often more sensitive to land-use or management than bulk SOM, it is still uncertain whether management effects are systematically reflected in the thermal behaviour of bulk SOM. Thermal properties of bulk soils from controlled long-term arable treatments under different fertilization regime are appropriate to check for systematic effects but to our knowledge have not been investigated so far.

Differential scanning calorimetry measures the differential heat flow of a sample (endo- or exotherm) relative to a reference as a function of temperature. Because thermal data are obtained relative rapidly and their measurement requires little sample preparation, thermal stability may have the potential to serve as an indicator for more complex attributes which are otherwise difficult to obtain, such as the distribution of SOM between biochemical labile and stabile fractions (Grisi et al. 1998). Moreover, measurements of coals and soot indicate that these compounds have thermal properties very much distinct from that of relatively recent, biogenic organic matter (hereafter called "natural") (Garcia et al., 1999; Boehman et al., 2005). Thus, a thermal screening might also help to distinguish between natural and coal or thermally altered organic matter.

Published by Copernicus GmbH on behalf of the European Geosciences Union. 


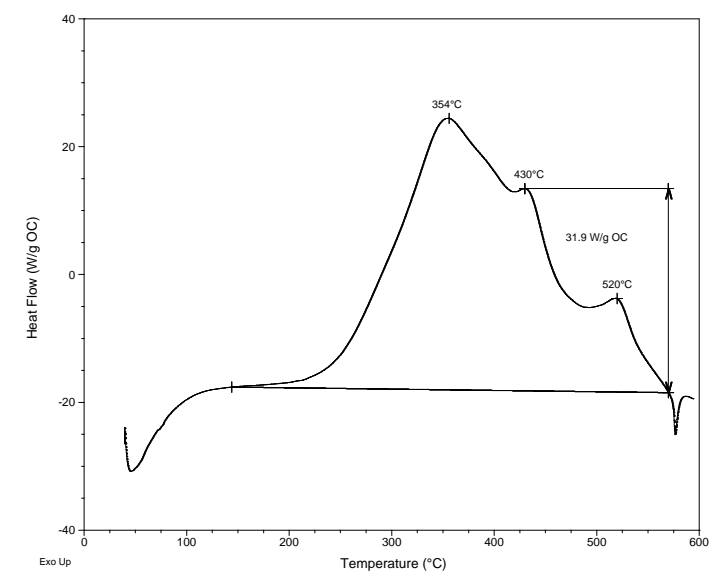

Fig. 1. DSC thermogram with exothermic peaks at $354^{\circ} \mathrm{C}, 430^{\circ} \mathrm{C}$, and $520^{\circ} \mathrm{C}$ and the endothermic quartz transition at $576^{\circ} \mathrm{C}$. The distance between peak maximum and baseline for the peak at $430^{\circ} \mathrm{C}$ exemplifies how peak heights were measured.

\section{Material and methods}

Samples were taken in 2004 from four treatments of the Extended Static Fertilization Experiment in Bad Lauchstädt, close to the city of Halle, Germany $\left(51^{\circ} 24^{\prime} \mathrm{N}, 11^{\circ} 53^{\prime} \mathrm{E}\right.$, altitude $113 \mathrm{~m}$ above sea, mean annual precipitation $484 \mathrm{~mm}$, mean annual temperature $8.7^{\circ} \mathrm{C}$ ). The soil is a loess-derived loamy Haplic Chernozem (FAO) with $22 \%$ clay. Total field size is 3.09 ha with individual parcels covering $265 \mathrm{~m}^{2}$. This long-term experiment consists of plots with continuous treatment since 1902 and a set of treatments that has been altered in 1978. The latter include organic matter-depleted plots that now receive farmyard manure and plots with former high SOM levels where farmyard manure application is now terminated. Composite samples from 25 replicates per field were taken from four treatments (null $\mathrm{N}$, change from null to manuring in $1978 \mathrm{NM}$, change from manuring to null in $1978 \mathrm{MN}$, and permanent manure and annual mineral fertilization since $1902 \mathrm{M}$ ) from 0 to $20 \mathrm{~cm}$ at different days of the year $(n=7)$. We chose the latter approach to distinguish long-term treatment effects from short-term noise induced by varying amounts of plant residues in the soil throughout the year. In the M plots, $30 \mathrm{tha}^{-1}$ farmyard manure is applied every second year (crop rotation: sugar beet, summer barley, potatoes, winter wheat). Detailed field set-ups are given in Körschens and Pfefferkorn (1998).

Thermograms were scanned with a differential scanning calorimeter DSC100 (TA Instruments) after heat flow calibration with sapphire and temperature and heat calibration with the melting of indium (Danley, 2003). In a range of previous experiments, we tested the dependence of the DSC parameters (heat flow, onset- and peak temperatures, and heat of reaction) on different sample $\mathrm{C}$ concentrations and derived an optimum sample weight of 0.2 to $0.5 \mathrm{mg} \mathrm{C}$. For

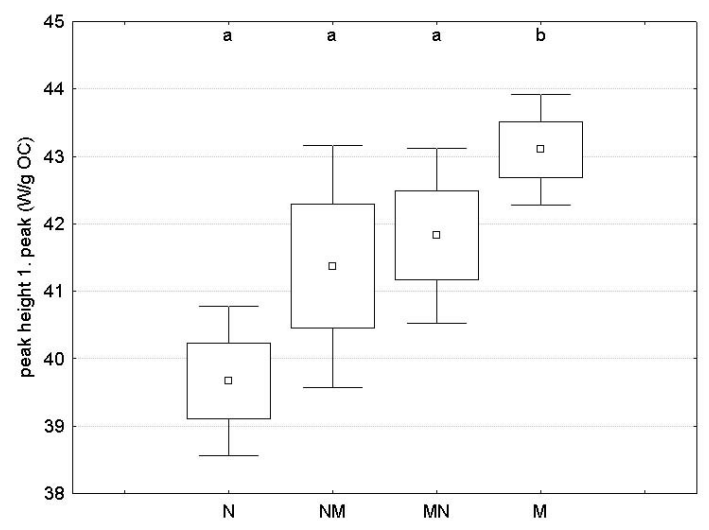

Fig. 2. Peak height of first exotherm for the four treatments. Box plots show mean, standard error SE, and 1.96* SE. Different characters indicate significant differences for means $(\mathrm{P}<0.05)$. $\mathrm{N}$ null plot without fertilization since 1902, M manure since 1902, NM change from null to manuring in 1978, MN change from manuring to null in 1978.

the results reported here, about $15 \mathrm{mg}$ finely ground dry material equivalent to around $0.3 \mathrm{mg} \mathrm{C}$ was weighted into an open aluminium pan. An empty Al-pan served as the reference. Samples were heated under a flow of synthetic air of $50 \mathrm{ml} \mathrm{min}^{-1}$ from room temperature to $600^{\circ} \mathrm{C}$ at a heating rate of $20^{\circ} \mathrm{C} \mathrm{min}^{-1}$. This flow allowed oxidizing conditions at any one point of reaction. DSC parameters used to characterize the stability of the materials were peak temperatures $\left({ }^{\circ} \mathrm{C}\right)$, peak heights $\left(\mathrm{W} \mathrm{g}^{-1}\right.$ soil or normalised to the organic $\mathrm{C}$ content of the sample by dividing the thermogram through the organic $\mathrm{C}$ content, $\mathrm{Wg}^{-1}$ organic $\mathrm{C}$ ), and total heat evolved $\left(\mathrm{J} \mathrm{g}^{-1}\right)$. Peak heights were measured as the maximum deviation from a linear baseline drawn between 150 and $568^{\circ} \mathrm{C}$.

Aliquots of the samples were $\mathrm{HCl}$ treated to remove carbonates, and organic carbon (OC) was measured after dry combustion in an $\mathrm{O}_{2}$-stream and detection of the produced $\mathrm{CO}_{2}$ by infrared absorption.

Thermal parameters passed tests for normality and homogeneity of variances. An ANOVA followed by a Scheffé-test was used to identify treatment-induced differences of means, and Pearson's coefficient was calculated to check for correlations.

\section{Results and discussion}

Soil organic carbon contents were highest for $\mathrm{M}$ $(2.38 \pm 0.03 \%$; mean \pm standard error), lowest for $\mathrm{N}$ $(1.73 \pm 0.02 \%)$, and similar for MN and NM $(2.16 \pm 0.02$ and $2.18 \pm 0.05 \%$, respectively). Historical records for all crops showed marked yield differences between $\mathrm{N}$ and $\mathrm{M}$ treatments. Together with the manure input, this explains the 


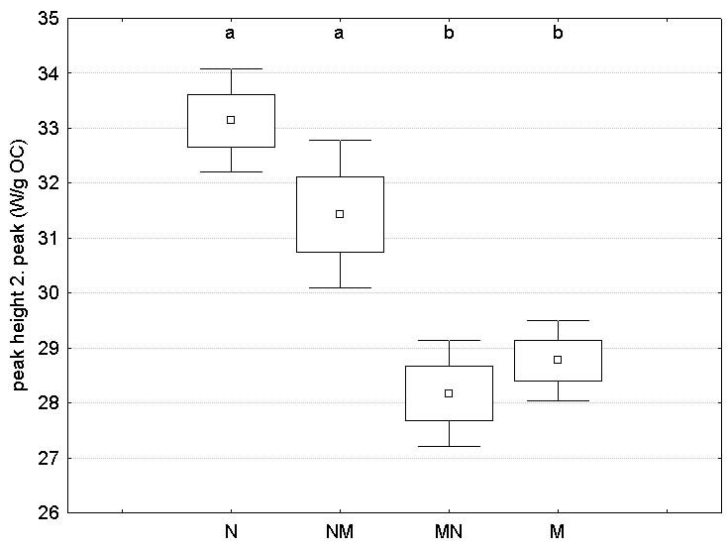

Fig. 3. Peak height of second exotherm for the four treatments. Box plots show mean, standard error SE, and 1.96* SE. Different characters indicate significant differences for means $(\mathrm{P}<0.05)$. N null plot without fertilization since 1902, M manure since 1902, NM change from null to manuring in 1978, MN change from manuring to null in 1978.

differences in soil OC content (Körschens and Pfefferkorn 1998).

Thermograms of all samples were virtually similar and characterized by three strong exotherms at around $354^{\circ} \mathrm{C}$, $430^{\circ} \mathrm{C}$, and $520^{\circ} \mathrm{C}$, and one endotherm at around $576^{\circ} \mathrm{C}$ attributable to a phase transition of quartz (Fig. 1). Peak temperatures of single exotherms were similar among the four treatments $\mathrm{N}, \mathrm{NM}, \mathrm{MN}$, and $\mathrm{M}$ (first peak $354.5 \pm 0.5$, $355.4 \pm 0.7,354.3 \pm 0.3,354.1 \pm 0.3$, second peak $428.6 \pm 0.8$, $430.8 \pm 2.2,428.9 \pm 1.1,429.5 \pm 1.2$, third peak $520.6 \pm 1.0$, $520.0 \pm 0.9,522.0 \pm 0.9,521.4 \pm 1.5)$. Peak heights were more variable than peak temperatures and compared between i) the four treatments and ii) the seven different days of the year when samples were taken. The latter comparison revealed no systematic pattern because both OC contents and thermal properties were related to the long-term fertilization regime rather than to variations throughout the year, and so only comparisons between treatments are reported.

The total heat evolved during oxidation was highly significantly correlated with the OC content of the samples ( $\mathrm{r}=0.91$, $\mathrm{P}<0.001)$. Also peak heights $\left(\mathrm{W} \mathrm{g}^{-1}\right.$ soil) of the first $(r=0.96, P<0.001)$ and the second peak $(r=0.74, \mathrm{P}<0.001)$ correlated significantly with the OC content whereas no correlation was found for $\mathrm{OC}$ and the height of the third peak $(\mathrm{r}=0.11, \mathrm{P}=0.58)$. The higher correlations between thermal properties and SOC in the lower temperature range are consistent with results obtained from thermogravimetry of bulk soils (Siewert, 2004). Together, these results suggest that the exothermic reactions mostly derive from organic matter oxidation, and that the heat evolved is roughly proportional to the amount of organic matter in the sample.

We found significant treatment effects for peak heights of the first and second exotherm (Figs. 2 and 3). Because peak

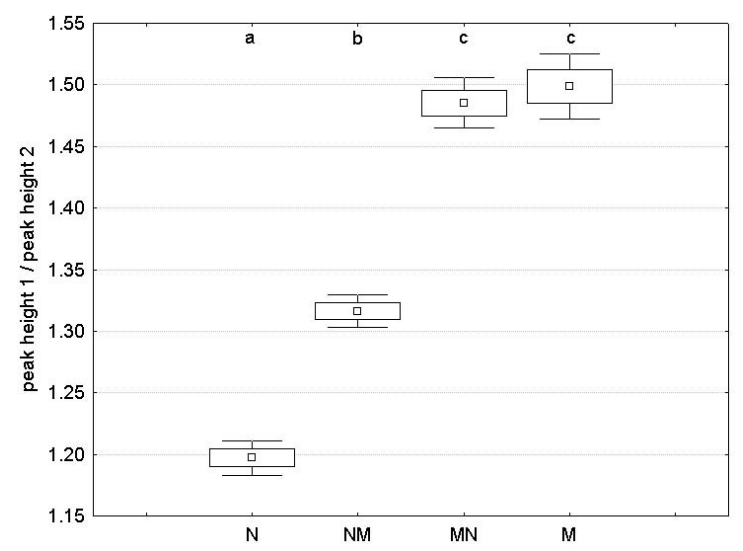

Fig. 4. Quotient of labile to stable SOM for the four treatments. Box plots show mean, standard error SE, and 1.96* SE. Different characters indicate significant differences for means $(\mathrm{P}<0.05)$. $\mathrm{N}$ null plot without fertilization since 1902, M manure since 1902, NM change from null to manuring in 1978, MN change from manuring to null in 1978.

heights were normalized to the $\mathrm{C}$ content of each sample, the difference is attributable to a fertilization-induced variation in SOM quality. In terms of thermal stability, the Null plot was characterized by the smallest proportion of labile and the highest of stabilized OC, and this pattern was reversed for treatment $\mathrm{M}$ receiving mineral plus manure fertilizer since 1902. Though their OC contents were the same, treatment effects between MN and NM could be clearly distinguished by peak heights of the second peak and by the ratio peak height peak one / peak height peak two (Fig. 4), implying a higher sensitivity of SOM quality than OC content to fertilization. Higher thermal stabilities of $\mathrm{N}$ compared to $\mathrm{M}$ treatments correspond to relatively higher proportions of labile $\mathrm{OC}$ in $\mathrm{M}$ than in $\mathrm{N}$ plots as measured by hot water extraction at the Bad Lauchstädt experiment (Körschens et al. 1998).

A direct comparison of peak temperatures between different DSC set-ups is hampered because peak temperatures are logarithmically related to the heating rate (ASTM, 2005). In a range of previous experiments we found that the $\mathrm{Bad}$ Lauchstädt exotherms at $520^{\circ} \mathrm{C}$ tracked at $20^{\circ} \mathrm{C} \mathrm{min}^{-1}$ correspond to peak temperatures of $496^{\circ} \mathrm{C}$ and $508^{\circ} \mathrm{C}$ at heating rates of 5 and $10^{\circ} \mathrm{C} \mathrm{min}^{-1}$, respectively, making data among different studies comparable to each other. The third peak is not typical for the oxidation of natural organic matter (see e.g. Dell'Abate et al., 2003; Shafizadeh, 1984), but charring during the experiment may form thermally stable compounds (Kaloustian et al., 2001). However, charring of cellulose and lignin, the main plant constituents, resulted in peaks much below $500^{\circ} \mathrm{C}$ (Shafizadeh, 1984; Kaloustian et al., 2001) when normalized to a heating rate of $20^{\circ} \mathrm{C} \mathrm{min}{ }^{-1}$. Together with our finding that the third peak was not correlated to the OC contents of the samples, we assume that this peak is attributable to compounds already in the soil. Several authors 
(Sonibare et al., 2005; Garcia et al., 1999; Boehman et al., 2005) observed exotherms above $500^{\circ} \mathrm{C}$ for the combustion of coals and soot. Conversely, peak temperatures during the combustion of various lignites were typically below $500^{\circ} \mathrm{C}$ at a heating rage of $10^{\circ} \mathrm{C} \mathrm{min}^{-1}$ (Kök, 2001). Chemical quantification methods (Schmidt et al., 1996) and ${ }^{14} \mathrm{C}$ dating (Rethemeyer et al., 2005) indicated that some soils near the city of Halle are affected by deposition of lignite dust or lignite-derived combustion products due to their vicinity to open cast mining, railway lines and lignite power plants. We suggest that lignite-derived reaction products rather than native lignite contribute to the thermal decomposable compounds at our site because the third peak occurred at higher temperatures than those in the study of Kök (2001).

Peak heights $\left(0.316 \pm 0.013 \mathrm{~W} \mathrm{~g}^{-1}\right.$ soil $)$ of the third peak were statistically not different between treatments. Because some clay minerals, kaolinite in particular, undergo dehydroxylation in that temperature region (e.g. Kakali et al., 2001), the observed exotherm at $520^{\circ} \mathrm{C}$ may be attenuated by endothermic reactions from clay mineral decomposition. Infrared spectra from all samples revealed very similar absorbance at $3695 \mathrm{~cm}^{-1}$ attributable to kaolinite (not shown), suggesting similar amounts of that mineral. In addition, we do not expect strong variations in the clay mineralogy and thus no treatment-specific effect because of the comparable small field size and the homogeneous parent material. Therefore, it seems likely that the deposition of lignitederived products was homogeneous over the whole experimental field and that a possible alteration in the soil's biological activity induced by variations in residue returns and manure inputs did not induce preferences in the degradation of thermal stable material.

In conclusion, the DSC measurements of the Static Fertilization Experiment in Bad Lauchstädt clearly indicated qualitative differences of the SOM with higher thermal stabilities of long-term depleted plots. DSC parameters were found to be more sensitive to management than bulk soil $\mathrm{C}$ contents and may thus serve as indicators also for biochemical SOM attributes. The higher thermal stability of lignite-derived products at this site refers to possible applications of DSC beyond the characterization of natural SOM.

Acknowledgements. The authors thank F. Müller for help in the lab.

Edited by: A. Neftel

\section{References}

ASTM: Standard test method for Arrhenius kinetic constants for thermally unstable materials using differential scanning calorimetry and the Flynn/Wall/Ozawa method (E-698-04), American Society for Testing and Materials, West Conshohocken, 2005.
Boehman, A. L., Song, J., and Alam, M.: Impact of biodiesel blending on diesel soot and the regeneration of particulate filters, Energy \& Fuels, 19, 1857-1864, 2005.

Dell'Abate, M. T., Benedetti, A., and Brookes, P. C.: Hyphenated techniques of thermal analysis for characterisation of soil humic substances, J. Sep. Sci., 26, 433-440, 2003.

Danley, R. L.: New heat flux DSC measurement technique, Thermochim. Acta, 395, 201-208, 2003.

Garcia, P., Hall, P. J., and Mondragon, F.: The use of differential scanning calorimetry to identify coals susceptible to spontaneous combustion, Thermochim. Acta, 336, 41-46, 1999.

Grisi, B., Grace, C., Brookes, P. C., Benedetti, A., and Dell'Abate, M. T.: Temperature effects on organic matter and microbial biomass dynamics in temperate and tropical soils, Soil Biol. Biochem., 30, 1309-1315, 1998.

Kakali, G., Perraki, T., Tsivilis, S., and Badogiannis, E.: Thermal treatment of kaolin: the effect of mineralogy on the pozzolanic activity, Appl. Clay Sci., 20, 73-80, 2001.

Kaloustian, J., Pauli, A. M., and Pastor, J.: Kinetic study of the thermal decompositions of biopolymers extracted from various plants, J. Therm. Anal. Calorim., 63, 7-20, 2001.

Kök, M. V.: An investigation into the combustion curves of Lignites, J. Therm. Anal. Calorim., 64, 1319-1323, 2001.

Körschens, M. and Pfefferkorn, A.: The static fertilization experiment and other long-term field experiments, UFZUmweltforschungszentrum Leipzig-Halle GmbH, 1998.

Körschens, M., Weigel, A., and Schulz, E.: Turnover of soil organic matter (SOM) and long-term balances - Tools for evaluating sustainable productivity of soils, J. Plant Nutr. Soil Sci., 161, 409-424, 1998.

Lopez-Capel, E., Sohi, S. P., Gaunt, J. L., and Manning, D. A. C.: Use of thermogravimetry-differential scanning calorimetry to characterize modelable soil organic matter fractions, Soil Sci. Soc. Am. J., 69, 136-140, 2005.

Plante, A. F., Pernes, M., and Chenu, C.: Changes in clayassociated organic matter quality in a $\mathrm{C}$ depletion sequence as measured by differential thermal analyses, Geoderma, 129, 186199, 2005.

Rethemeyer, J., Kramer, C., Gleixner, G., John, B., Yamashita, T., Flessa, H., Andersen, N., Nadeau, M. J., and Grootes, P. M.: Transformation of organic matter in agricultural soils: Radiocarbon concentration versus soil depth. Geoderma, 128, 94-105, 2005.

Satoh, T.: Organo-mineral complex status in soils. I. Thermal analytical characteristics of humus in the soils, Soil Sci. Plant Nutr., 30, 1-12, 1984.

Schmidt, M. W. I., Knicker, H., Hatcher, P. G., and Kögel-Knabner, I.: Impact of brown coal dust on the organic matter in particle size fractions of a Mollisol, Org. Geochem., 25, 29-39, 1996.

Siewert, C.: Rapid screening of soil properties using Thermogravimetry, Soil Sci. Soc. Am. J. 68, 1656-1661, 2004.

Sonibare, O. O., Ehinola, O. A., Egashira, R., and KeanGiap, L.: An investigation into the thermal decomposition of Nigerian Coal, J. Appl. Sci., 5, 104-107, 2005.

Shafizadeh, F.: The chemistry of pyrolysis and combustion, in: Chemistry of Solid Wood, edited by: Rowell, R., Advances in Chemistry Series 207, American Chemical Society, Washington D.C., 489-529, 1984. 